\title{
The Equivalence and Shift in the Persian Translation of English Complex Sentences with wh-Subordinate Clauses
}

\author{
Parisa Farrokh \\ English Department, Islamic Azad University of Lahijan Branch \\ PO box 1616, Kashef Street, Islamic Azad University, Lahijan, Iran \\ Tel: 98-912-359-4730 E-mail:p_farrokh@yahoo.com
}

Received: June 20, 2011

Accepted: July 4, 2011

Published: December 1, 2011

doi:10.5539/ells.v1n2p74

URL: http://dx.doi.org/10.5539/ells.v1n2p74

\begin{abstract}
The main purpose of this research is to find the types of equivalence and shifts in the Persian translation of English complex sentences with wh-subordinate clauses. This study uses a qualitative descriptive method. The English fictions and their Persian translations considered as source of the data.

The researcher classifies the data into two main categories: the equivalence and shift. The equivalence is subcategorized into formal and dynamic equivalence based on Nida's theory.

In this research, four categories of shift, based on Catford's classification, which involve structure shifts, unit shifts, rank shifts and intra-system shifts, have been found. Based on 160 data, the results of this research indicated that in the Persian translation of these sentences, the shifts occur more than the equivalence, with the percentage of $86.25 \%$ and the equivalence with the percentage of $13.75 \%$.
\end{abstract}

Keywords: Translation, Translator, Equivalence, Shift, Complex Sentences

\section{Introduction}

Translations are by definition, written for new situations, purposes, recipients and cultures. When you learn to translate, you have to learn how to gain an overview of a new situation with all its different factors. (Risku, 2002, p. 526). Therefore in translation, translators do many things and also get so many things. The translators face many difficulties while turning a source text into a target text. The final relationship between the two texts is something we have traditionally referred to as equivalence either in some ideal sense or more technically as some kind of relevant similarity. In other words, equivalence focuses to cases where languages describe the same situation by different structure. Whereas, when the form in the source language has a new form or different form from the target language, it is called shift. According to Catford as cited in Malmkjaer (2005), the technical term shift describes translation shift as the small linguistic changes in translation of source language into the target language. It seems that shifts indicate textual differences and dissimilarities; however, similarities indicate textual equivalences. It can be said that having complete mastery over the grammatical structures of both the source and target languages and also being aware of the notions and applications of shifts and equivalence, in order to present the best translation of an original text, are necessary for a translator. This research tries to find out the equivalence and shifts in form and meaning in the Persian translation of English complex sentences with wh-subordinate clauses. As these sentences are the fundamental type used in academic writing and thus a major feature in the reading and writing of ESL/EFL learners, so having complete knowledge about structure of these sentences, their application and translating into Persian can be useful for Iranian translators, translator trainees and English learners. Due to differences existing between English and Persian complex sentences, they may be confused in differentiating the types of clauses and even the position of clauses in English complex sentences while translating into Persian; therefore, they make mistakes. Most of the time they translate word by word or literal translation. These mistakes can be appeared even in writing or speaking of Iranian English learners. Analyzing and describing of Persian translation of English complex sentences with wh-subordinate clauses is the main object of this study. For this purpose, two notions-equivalence and shifts-have been considered. For analyzing of equivalence, Nida's formal and dynamic equivalence has been used. Regarding formal equivalence, the researcher investigates the Persian translation of subjects, objects, and predicates of English clauses. Catford's categories of shifts, involving structure shifts, unit shifts, class shifts and intra-system shifts has been used in this study.

Regarding structure shifts, the researcher studies shifts in the position of main and subordinate clauses, the addition 
of conjunctive word "ke" in Persian translations and converting of English complex sentences into Persian simple sentences. Unit shifts' investigation involves changing of English clauses into sentences and also changing of English phrases into words in Persian. The researcher studies class shifts based on changing in parts of speech. Intra-system shifts involve changing of English plural nouns into Persian singular nouns and vice versa. In this relation, the research questions have been formulated as follows: what are the types of equlvalence in the Persian translation of English complex sentences with wh-subordinate clauses? what are the types of shifts in the Persian translation of English complex sentences with wh-subordinate clauses?

\section{Translation and Translator}

According to Zauberga (2003) the production of translation is based on the translators' careful assessment of the recipient and the purpose of the target text. So, the translator makes the decision about translating strategy and treatment of the source language terms and structures (P. 88).

Nida (1964) believes that, the problem for the translator is that the translator is under constant pressure from the conflict between form and meaning (P. 19). It is obvious that translation peers always encounter different changes in equivalence within various language levels ranging from physical forms into meaning. The translator's task is not always how to understand the nature and conditions of the source language but also how to define the nature and conditions of translation equivalence. Besides that considering differences between target and source languages is another task of a translator, which regarded as shifts. Generally, it is clear that equivalence and shift are the important elements in the process of translation.

\section{Equivalence}

Equivalence is a central concept in translation theory, but it is also a controversial one. Baker (1998) uses the notion of equivalence for the sake of convenience because most translators are used to it rather than because it has any theoretical status (P. 77). Baker extends the concept of equivalence to cover similarity in source text and target information and in the cohesive roles, source text and target text devices and calls these two factors combined textual equivalence (ibid). Newman (1994) as cited in Baker (1998) stresses that not all the variables in translation are relevant in every situation and the translators must decide which consideration should be given priority at any one time, thus establishing a kind of functional equivalence (P. 77). Malmkjaer (2005) argues that for Catford, translation equivalence can almost always be established at sentence rank. In contrast, Nida's fundamental measure of translation equivalence is reader response.

Nida draws his famous distinction between formal and dynamic equivalence. Formal equivalence focuses attention on the message itself, in both form and content. In contrast a translation attempts to produce dynamic equivalence is based upon the principle of equivalent effect (ibid). Therefore the relationship between receptor and message should be substantially the same as the source language. In this research Nida's point view of equivalence has been used.

\section{Shifts}

The term shifts is used in the literature to refer to changes which occur or may occur in the process of translation. Malmkjaer (2001) quotes Larson (1997) views shift as the mismatch at the structure while New mark refers to the same concept as transposition. Basically the shift should be viewed on the consequence of translator's effort to establish translation equivalence, between two different language systems. Popovic (1970) as cited in Baker (1998) distinguishes between constitutive shifts which are system-bound and individual shifts that are prompted by the stylistic propensities and the subjective idiolect of the individual translator (P. 229). According to Catford (1965) shifts are departures from formal correspondence in the process of going from the source language to the target language. Catford distinguishes two major types of shifts; level shifts (where source language item at one linguistic level for example grammar has a target language equivalent at a different level, for instance lexis) and category shifts which involve (a) structure shifts, for example a subject-predicate-object structure maybe translated as a predicate-subject- object structure, (b) unit shifts for example a word may be translated by a morpheme (c) class shifts, for example an adjective maybe translated by a noun and (d) intra-system shifts, for example when the source language singular nouns translated as plural nouns in target language. As mentioned, Catford's category of shifts has been considered in this research.

\section{Complex Sentences}

A complex sentence combines a simple sentence (often called an independent clause or main clause) with a subordinate clause. These sentences are the fundamental type used in academic writing and thus a major feature in the reading and writing of ESL/EFL learners.

These sentences can be used to judge whether a work is written in a good way or not. By using more complex sentences, it can show the mature thinking of the writer. The using of complex sentences in the paragraphs makes 
the readers do not have monotonous sense to the work and show the emputhy of the paragraph (Fauzanah, 2009, P. 15).

In English, complex sentences come in many varieties based on types of subordinate clauses that are available. Subordinate clauses are divided into two major types; finite and non-finite clauses (Quirk, Greenbaum, Leech, Svartvik, 1987). Finite clauses are the basic subordinate clauses which include (1) adverbial clauses (2) noun clauses (3) wh- clauses (4) relative clauses. Non-finite clauses are those that do not have tense or modality and include infinitives and participles.

In Persian, sentences are classified into two main categories: (1) simple sentence and (2) compound sentence. A simple sentence contains one verb. Compound sentence is a sentence in which either one or more clauses are embedded. Conjunctive words or groups are used in these sentences. Compound sentences are two types: (1) continuous compound sentences or identity (2) Interdependent compound sentences or dependency (Farshidvard, 2009, P. 119). Continuous compound sentences consist of identical clauses and coordinative conjunctions like [væ], [ya] and so on which may be used in these sentences.

Independent compound sentences involve main and subordinate clauses. Based on the conjunctive words which are used in the beginning or middle of subordinate clauses, there are different types of subordinate clauses like time, place, conditional, manner and etc. (ibid).

\section{Research Method}

The purpose of this study is to show the equivalence and shifts involving in Persian translation of English complex sentences containing wh-subordinate clauses. This research deals with analyzing of data based on Nida's equivalence theory and Catford's category of shifts and uses a descriptive qualitative method.

\subsection{Materials}

The materials chosen for the analysis are English fictions which involve the novels of The Old Man and The Sea written by Hemingway, Animal Farm written by Orwell and Joyce's Dubliners (short stories).

160 complex sentences with wh-subordinate clauses along with their translation into Persian taken from Asha(2000), Hosseini \& Saffariyan(2007), Balouch(2010), Daryabandari(2010) and Firouzbakht(2009) have been analyzed based on Nida's equivalence theory and Catford's category of shifts.

\subsection{Procedures}

The data are classified into two main categories: the equivalence and shift. The equivalence is subcategorized into formal and dynamic equivalence. The Category shift is classified into structure shifts, unit shifts, class shifts and intra-system shifts.

\subsection{Formal Equivalence}

6.3.1 SL subjects of clauses are translated into TL subjects of clauses

\section{You know how people gossip.}

[šoma] [midanid] [mordom] [ĉetor] [qeyboet] [mikoncend].

You $=[$ šoma $]$ people $=[$ mærdom $]$

subject=subject

\section{I will show him what a man can do.}

[moen] [be] [u] [nešan] [xahcem] [dad] [ke] [yek] [moerd] [če] [karha] [mitcevanced] [bekonced].

$\mathrm{I}=[\mathrm{mæn}]$ a man $=[\mathrm{yek}][\mathrm{mærd}]$

subject=subject

6.3.2 SL predicates of clauses are translated into TL predicates of clauses

\section{When he was alive.}

[voeqti] [u] [zendeh] [bud].

alive $=$ [zendeh $]$

predicate $=$ predicate

When he was alone.

[voeqti] [u] [tcenha] [mišod]. 
alone $=[$ tænha $]$

predicate $=$ predicate

6.3.3 SL objects of clauses are translated into TL objects of clauses

When they had sold it.

[če] [voeqt] [anha] [ra] [furuxtehoend].

$\mathrm{It}=[\mathrm{an}]$

object $=$ object

You loved him.

[to] [uno] [dust] [dašti].

him=[un]

object $=$ object

6.4 Dynamic Equivalence

He never thought about the past when he was doing it.

[u] [dcer] [gcermagcermekar] [horgez] [be] [gozcešteh] [nemiycendišid].

I wonder why he jumped in the air.

[nemidancem] [čera] [cez] ] [ab] [birun] [ parid].

6.5 The Shifts

6.5.1 Structure Shifts

6.5.1.1 Shifts in the position of main and subordinate clauses

I woke when Rinaldi came in.

[vceqti] [rinaldi] [amced] [bidar] [šodcem].

When Rinaldi came in $=$ [væqti] [rinaldi] [amæd].

We have won back what we had before .

[čizi] [ra] [ke] [qceblcen] [daštehim], [paes] [gereftehim].

We have won back $=[$ pæs $]$ [gereftehim].

6.5.1.2 The addition of conjunctive word "ke" in Persian translation

I knew where he was going to go.

[midanestcem] [ke] [u] [koja] [qcerar][bud] [bercevced].

He asked me where I was going.

[cez] [moen][porsid][ke][koja][mixahcem][bercevcem].

6.5.1.3 Changing English complex sentences into Persian simple sentences

Four pigs had protested when Napoleon abolished the Sunday Meetings.

[čahar] [xuk] [be] [loeqve][ j jelcesate] [yekšcenbeha] [tcevcesote] [napelon][?eteraz] [kcerdcend] .

The boy and I will splice them when we are home.

[mæen] [o][pescercek][dcer][xaneh] [scerhœemešan][mikonim].

6.5.2 Unit Shifts

6.5.2.1 SL clauses translated into TL sentences

I don't know why I wanted it so much.

[nemidancem][čera] [inqcedr][mixastcemceš].

I don't know=[nemidanæm]

clause $=$ sentence

He knew where he would meet the boys. 
[midanest][bcečeharo][koja][peyda][konced].

He knew $=[$ midanest $]$

Clause $=$ sentence

6.5.2.2. SL Phrases translated as words in TL

I don't know what the fish is going to do.

[nemidancem][mahi][če][xiyali][dare].

The fish $=[$ mahi $]$

phrase $=$ word

I wonder what the sea looks like from that height.

[nemidancem] [dcerya] [cez] [an][bala][če][šekli][cest].

The sea $=$ [dærya]

pharse $=$ word

6.5.3 Class Shifts

You know what the real reason was.

[midanid][hoeqiqcete] [moetlceb][čist].

real = hæqiqæt

adjective $=$ noun

He knew exactly what it was.

[xub][midanest][ke][čist].

exactly $=[\mathrm{xub}]$

adverb=adjective

6.5.4 Intra-system Shifts

Four pigs had protested when Napoleon abolished the Sunday Meetings.

[čahar][xuk][be] [loeqve] [ ॅ jolcesate] [yekšcenbeha][tcevcesote][napelon][?eteraz][kcerdoend].

Sunday $=[$ yekšænbeha]

singular=plural noun

I know where I can get four baits too.

[tazeh][miduncem][cez][koja][mišcevoed] [čahar][ta][to?meh] [hoem][geref].

four baits $=[$ čahar $][$ to? $\mathrm{m} \mathrm{eh}]$

plural noun=singular noun

\section{Data Findings}

In this research, there are two main categories namely equivalence and shift. Based on 160 data, 22 data of equivalence or $13.75 \%$ and 138 data of shift or $86.25 \%$ were found Table 1 . Therefore the shifts occur more often in the translation of English complex sentences with wh-subordinate clauses into Persian than the equivalence.

Table 2 shows the total number and percentage of formal and dynamic equivalence, formal equivalence with the percentage of $77.25 \%$ and dynamic equivalence with the percentage of $22.75 \%$. Table 3 indicates the subcategories of formal equivalence which contain the translation of SL subjects, predicates and objects with the percentage of $31.82 \%, 13.64 \%$ and $31.82 \%$ respectively. Table 4 shows the categories of shifts involving structure shifts with the total percentage of $48.56 \%$ which are divided into three subcategories in this study: (a) shift in the position of main and subordinate clauses with the percentage of $15.22 \%$ (b) the addition of conjunctive word "ke" in the Persian translation of English clauses with the percentage of $16.67 \%$ and (c) changing English complex sentences into Persian simple sentences with the percentage of $16.67 \%$.

Table 4 also indicates the unit shifts with the total percentage of $46.36 \%$, divided into two sub-groups in this research as (a) SL clauses translated as TL sentences with the percentage of $40.57 \%$ and (b) SL phrases translated as words in TL with the percentage of $5.79 \%$. According to Table 4 the percentage of class shifts is $2.90 \%$ and the 
intra-system shifts is $2.18 \%$.

\section{Discussion and Conclusion}

Regarding the equivalence it can be said that the translators ,in some cases, use dynamic equivalence in translation of English complex sentences with wh-subordinate clauses such as in He never thought about the past when he was doing it which has been translated as[u] [dcer] [gcermagcermekar] [hcergez] [be] [gozcešteh] [nemiycendišid], the clause of "when he was doing it" has been translated as [dær gærmagærmekar] which is the equivalence of the English phrase [In the heat of the work].The translator has used [dær gærmagærmekar]as a dynamic equivalence aims at complete naturalness of the expression. Another example is I wonder why he jumped in the air translated as [nemidancem] [čera] [cez] ] [ab] [birun] [ pcerid]in Persian. [æz ab] is a phrase which has been added to the verb [jump] as [æz ab birun pærid] according to the context, making it more comprehensible in Persian. However, the equivalence of the verb [jumped] in Persian is [Pærid]. According to the results of this study, it has been cleared that in the Persian translation of English complex sentences containing wh-subordinate clauses, the position of main and subordinate clauses, especially in subordinate clauses with wh-words like when and what, is reversed. For example in I woke when Rinaldi came in and the Persian translation of it [væqti] [rinaldi] [amæd], [bidar] [šodæm], the clause [væqti] [rinaldi] [amæd] is the subordinate clause and the translation of English subordinate clause when Rinaldi came in, which precedes main clause in Persian. Another structure shift found in this study is the addition of conjunctive word ke between clauses starting with wh-words like where, which and who .For example, [midanestæm] [ke] [u] [koja] [qærar][bud] [berævæd] which is the translation of I knew where he was going to go. Moreover English complex sentences with wh-subordinate clauses may be translated as Persian simple sentences, such as Four pigs had protested when Napoleon abolished the Sunday Meetings, translated as:

[čahar][xuk][be][læqve][ $\mathrm{j}$ ælæsate][yekšænbeha][tævæsote][napelon][?eteraz][kærdænd], regarded as a simple sentence in Persian.

It should be noted that since in Persian, the verbs determiner is in agreement with the subject of sentences therefore most of the time, if the subject is pronoun, then it will not be translated in Persian, like I don't know=[nemidanæm], in Persian translation[æm] is the translation of pronoun I, which has been used instead of the pronoun[mæn].So unit shift occurs here that is the conversion of clause into sentence in target language. Other unit shift found in this paper is changing of English phrases into Persian words which occurred more in translation of English definite article since in some cases, it had not been translated in Persian translation of English complex sentences with wh-subordinate clauses; such as The fish $=$ [mahi].

Class shift also occurs in translation of English complex sentences containing wh-subordinate clauses, for example in You know what the real reason was, the word [real] has been translated as [hæqiqæt] in Persian which is a noun while[real]is an adjective in the source language.

Intra-system shift found in this study is that there is not agreement between number and word so that English plural nouns translated as Persian singular nouns such as four baits= [čahar] [to? $\mathrm{m}$ eh], baits is a plural noun which is translated as [to? $\mathrm{m}$ eh],that is singular noun although it is preceded by the number [čahar].

Based on the results of this study, it can be concluded that in the Persian translation of English complex sentences with wh- subordinate clauses, the shifts occur more often than the equivalence. The researcher also concluded that the equivalence is not similar form and moreover the forms may change but meaning must not.

In dynamic equivalence, although, the form is different but one thing is important, the meaning is the same. Whereas shifts can be considered as the consequence of translators effort to establish translation naturalness between different languages. According to Fauzanah (2009) the occurrence of shifts reflect the translator's awareness of the linguistic and non-linguistic discrepancies between SL and TL (P.13).

In this case shifts can be defined as problem solving strategies adapted consciously to minimize the inevitable loss of meaning when rendering a text from one language into another language. Moreover, it seems that in the literature of translation studies and in translation classrooms, students and learners are required to compare and contrast translations with their originals. It is useful for language learning, translation education, translation studies, lexicography, finding equivalents for SL expressions, terms, structures and so on. It is hoped that the results of the research may be used as additional information for the teachers especially in teaching English grammar and translation courses. Also, the results may help Iranian translators, English learners and translator trainees for being able to provide the best translation of English complex sentences with wh-subordinate clauses.

\section{References}

Asha, S. (2000). Contrastive translation of the old man and the sea. (3rd ed.). Tehran: Rahnama Publication. pp. 8-194 
Baker, M. (1998). Routledge encyclopedia of translation studies. London and New York: Routledge. http://dx.doi.org/10.4324/9780203359792

Balouch, H. R. (2010). Animal farm. Tehran: Majid Publication. pp. 37-80

Catford, J. C. (1965). A linguistic theory of translation. An essay in applied linguistics. Oxford:Oxford University. pp. 33-35

Daryabandari, N. (2010). The old man and the sea. (3rd. ed.). Tehran: Kharazmi Publication. pp. 132-186

Farshidvard, K. (2009). Today's comprehensive grammar. (3rd ed.). Tehran: Sokhan Publication.

Fauzanah, R. (2009). A translation analysis of complex sentences in novel "The Scarlet Letters" and its translation. Research paper for B.A degree. Indonesia: Muhammadaiyah University of Surakarta.

Firouzbakht, M. (2009). Animal farm. (2nd ed.). Tehran: Sokhan Publication. pp. 79

Hosseini, S., \& Saffariyan, M. A. (2007). Dubliners and the criticise of Dubliners. (9th ed.). Tehran: Niloofar Publication. pp. 45-187

Malmkjaer, K. (2005). Linguistics and the language of translation (9th ed.). Edinburgh: University Press Ltd. pp. 24-30

Nida, E. A. (1964). Toward a science of translating: With special reference to principles and procedures. Bible translation (2nd ed.). Leiden: E.J. Brill.

Quirk, R., Greenbaum, S., Leech, G., \& Svartvik, J. (1987). A comprehensive grammar of the English language (5th ed.). London and New York: Longman. pp. 992-1006

Risku, H. (2002). Situatedness in translation studies. Frankfurt Am Main: Vervuert Verlag.

Zauberga, I. (2003). Translation related convention shifts in Latvian cookery books. A symposiumon didactics and research. Aarhus, Denmark: Hermes Skriftserie.

Table 1. The total number and percentage of the equivalence and shifts

\begin{tabular}{|l|c|c|}
\hline & Total & Percentage \\
\hline Equivalence & 22 & 13.75 \\
\hline Shift & 138 & 86.25 \\
\hline
\end{tabular}

Table 2. The total number and percentage of formal and dynamic equivalence

\begin{tabular}{|l|c|c|}
\hline & Total & Percentage \\
\hline Formal Equivalence & 17 & 77.25 \\
\hline Dynamic Equivalence & 5 & 22.75 \\
\hline
\end{tabular}

Table 3. The analysis of formal equivalence

\begin{tabular}{|l|c|c|}
\hline Formal Equivalence & Total & Percentage \\
\hline SL subjects of clauses are translated into TL subjects of clauses & 7 & 31.82 \\
\hline $\begin{array}{l}\text { SL predicates of clauses are translated into TL predicates of } \\
\text { clauses }\end{array}$ & 3 & 13.64 \\
\hline SL objects of clauses are translated into TL objects of clauses & 7 & 31.82 \\
\hline
\end{tabular}


Table 4. The analysis of category shifts

\begin{tabular}{|l|l|c|c|}
\hline & \multicolumn{1}{|c|}{ Total } & Percentage \\
\hline 1 & Structure shifts & 67 & 48.56 \\
\hline & $\begin{array}{l}1.1 \text { Shifts in the position of main and subordinate } \\
\text { clauses }\end{array}$ & 21 & 15.22 \\
\hline & 1.2 The addition of conjunctive word' "ke" & 23 & 16.67 \\
\hline 2 & $\begin{array}{l}1.3 \text { Changing English complex sentences into Persian } \\
\text { simple sentences }\end{array}$ & 23 & 16.67 \\
\hline & $\begin{array}{l}\text { Unit shifts } \\
2.1 \text { SL clauses translated into TL sentences }\end{array}$ & 64 & 46.36 \\
\hline 3 & Class shifts & 56 & 40.57 \\
\hline 4 & Intra - system shifts & 3 & 2.79 \\
\hline
\end{tabular}

